\title{
Bongó Itá: leopard society music and language in West Africa, Western Cuba, and New York City
}

\author{
Ivor L. Miller* \\ Research Fellow, African Studies Center, Boston University, USA
}

\begin{abstract}
The Abakuá mutual-aid society of Cuba, recreated from the Ékpè leopard society of West Africa's Cross River basin, is a richly detailed example of African cultural transmission to the Americas. Its material culture, such as masquerades and drum construction, as well as rhythmic structures, are largely based on Ékpè models. Its ritual language is expressed through hundreds of chants that identify source regions and historical events; many can be interpreted by speakers of Efik, the pre-colonial lingua franca of the Cross River region (Miller 2005). With the help of both Ékpè and Abakuá leaders, I have examined relationships between the musical practices of West African Ékpè, Cuban Abakuá, as well as Cuban migrants to the United States whose commercial recordings have evoked West African places and events historically relevant to Abakuá, meanwhile contributing to the evolution of North American jazz.
\end{abstract}

Keywords: Abakuá; Calabar; Cross River region; Cuba; Ékpè leopard society; jazz; Nigeria

\section{The Ékpè Imperium}

The leopard society of the Cross River basin is known variously as Ékpè, Ngbè, and Obè, after local terms for 'leopard'. ${ }^{1}$ Being among the most diverse linguistic regions in the world, to simplify, I will hereafter use Ékpè, an Ėfik term, the most common in the existing literature. Hundreds of Cross River principalities each possessed their own Ékpè lodge, a symbol of their autonomy, where matters concerning local governance were settled in councils, until colonial rule at the end of the nineteenth century. While Ékpè lodges still exist, their primary function as a traditional police force has largely been replaced by the modern police. Few details are known about Ékpè history, but from contemporary oral history and from colonial reports, themselves largely based upon oral history, we learn that after continuous contact with European merchants was established in the late 1600s, Ékpè was restructured by the Ėfik-speaking traders whose beachhead settlements on the Calabar River received European cargo ships. As the European demand for slaves grew (from the 1650s to the 1840s), Éfik traders expanded their networks to include the entire Cross River basin, extending eastwards into present-day Cameroon and northwards to the Árù ('Arochukwu') trading oligarchy (see Manfredi 2004, p. 239), encompassing all the Cross River communities mentioned in this essay, where languages such as Balondo (Efut), Éjághám, İbìbìo, Órón, and Umon were (and still are) spoken. Many settlements in the reach of the expanding Èfik trading empire already

\footnotetext{
*Email: imiller@hampshire.edu 
possessed forms of Ékpè (as many of their contemporary leaders claim). Nevertheless, Èfik merchants transmitted their own forms of Ékpè to many other communities in the context of trade relationships. The result, according to one Cross River historian, was an Ékpè Imperium (see Anwana 2009). Being the dominant form of inter-ethnic communication, the ceremonial practices of Ékpè reflect a rich variety of languages, costumes, music, and dance of the entire region. As the European demand for slaves increased, competition among dominant Èfik settlements for access to the cargos ships intensified, resulting in several battles where some Cross River Ékpè members were enslaved and carried to the Caribbean.

\section{Calabarí Diaspora}

The transatlantic slave trade transferred many thousands of people from southeastern Nigeria and southwestern Cameroon throughout the Americas, where they were known as 'Calabarí' or 'Carabalí', after the port city of Old Calabar from which many departed. From the well-known Calabarí presence in Florida, Louisiana, and South Carolina, to the neighborhood of Calabar in Salvador, Brazil, to the Calabar High School in Kingston, Jamaica, to the 'Carabalí' nation-groups of colonial Cuba, Calabarí presence was nearly ubiquitous (Hall 1992, p. 299; Landers 1999, pp. 48-49; Wood 1974, p. 339).

The island of Cuba received significant elements of Cross River influence in the form of oral historical narratives that continue to be transmitted in apprenticeship systems. Many narratives memorializing places, and ethnic terms of the Cross River region are maintained by members of the Cuban Abakuá, a mutual aid society established in colonial Havana, Cuba, in 1836, by free male Africans and their descendants (Trujillo 1882, p. 364; Miller 2009). Multiple sources of evidence demonstrate that Abakuá was derived principally from the 'leopard societies' of the Àbàkpà (Qua-Éjághám), Balondo (Efut), Èfîk, İgbo, Umon, and Uruan peoples of the Cross River basin (Old Calabar), in southeastern Nigeria and southwestern Cameroon.

\section{Triangular research strategies}

Since 1959, information about the Abakuá has been inaccessible to most non-Cuban scholars. After commencing research in Havana in 1991, I have also worked with Abakuá members living in the USA, gathering and interpreting their historical narratives about the Calabar past as maintained in their chants.

Abakuá leaders narrated to me the African sources of their society in the Abakuá ritual language, as well as the history of its recreation in colonial Cuba. They included Spanish interpretations of hundreds of chants containing a variety of phrases of West African provenance.

Responding to my write up of Abakuá music in 2000, Nigerian members of the Cross River Ékpè society living in the USA informed me that they recognized the chants as transcribed and interpreted in my essay as part of their own history. Thus began an international conversation - between leaders of the Cuban Abakuá, West African Ékpè members, and myself - about the implications of their shared 
cultural practices for historiography, as well as for contemporary activities like festivals and solidarity.

Soon afterwards, in 2001, I facilitated what was perhaps the first meeting between Cuban Abakuá and West African Ékpè at the Èfîk National Association meeting in New York. Astonished at the similarities in the performance of the Cuban masquerades to their own, several Ėfik leaders helped interpret Cuban chants, the preliminary results of which appeared in African Studies Review (Miller 2005).

In Calabar from 2004 to 2005, after presenting Ékpè leaders with information about Cuban Abakuá, I learned that the results of my study are of great interest to the leadership of the leopard societies in all three regions, who seek information about their kindred practices, in order to reinforce their own local variant.

During my first visit to Calabar, Ékpè leaders made it clear that a prerequisite to my field research on their society was joining it. After accepting this condition, my capacity as intermediary was sanctioned by traditional Ékpè leaders in Calabar, by their bestowal upon me of the chieftaincy title 'Mbàkàrà'. This initiation in effect authorized my travel throughout the Cross River region to speak with Ékpè leaders about Ékpè business, while making me an unofficial Ékpè ambassador to the Americas.

In the 1940s anthropologist Melville Herskovits (1948, p. 10) asserted that 'research among the Negro peoples of Africa and the New World represents no more than work on different parts of but a single field of study'. My own experience with transatlantic 'Calabari' culture has so far borne witness to Herskovits's statement. The triangular research strategies that led to the writing of this essay identify the musical practices of West Africa's Ékpè society and its descendants in Western Cuba and New York City as part of a continuous tradition with rich variations.

\title{
West African Ékpè history and aesthetics in Cuban Abakuá chants
}

\author{
Ékue Usagaré akuaramina Usagaré \\ Ékpè began in Usagaré \\ (Cuban Abakuá march)
}

Cuban Abakua lore indicates that 'Usagaré' was the source community of their society in West Africa. Cross River Ékpè also regard 'Usaghade' as a source for the esoteric aspects of their traditions. Lying near the coastal Atlantic border of Nigeria and Cameroon, 'Isangele' is close to the city of Calabar in the Cross River basin. Isangele is the colonial name; locals call it Usak-Ade, essentially the same pronunciation as that of Cuban Abakuá.

Prince Mosongo, a member of the noble founding family of Usaghade, wrote a history of his community called An X-Ray on Bakassi Peninsular, claiming that 'I have been directed by our Ancestors and unanimously agreed by the entire tribe to present this book.' Mosongo (1995, p. 5) aims to 'provoke intensive research into our various Isangele controversial clans, that would enable us to invite specialists to finally provide explicit chronologies for our events and summarize our history ...' In their search for their local history, little did Cross River people expect that evidence would be found in the chants of their spiritual descendants, the Cuban 
Abakuá. During the early period of the transatlantic slave trade, according to legend, the Èfik traders of Old Calabar received fundamental elements of Ékpè from Usaghade (Miller 2009, pp. 46-47). After making elaborations, they transmitted their 'modern' form of Ékpè throughout their trading empire.

From a Cross River region far northwest of Usaghade, İbibì̀ musicologist Samuel Akpabot learned that, as in Cuba, local mythology points to the transmission of Ékpè from Usaghade: 'Tradition has it that Ékpè originally came from a place called Usangade [sic] where the Efot ethnic group live in the [peninsula near] Calabar; it was they who let the İbibì people of Uruan into the secrets of the cult.' Part of the evidence for this history is that İbibì Ékpè use a non-İbibì̀ language in ceremony. Akpabot (1975, p. 32) wrote:

Members of the Ékpè society greet one another with these code words: Cantor: Uyo bari bari nya nkpe ... These words are not easy to translate into English since they are not İbibì words and their origin is not easily traceable. They are more like nonsense words with a special meaning to Ékpè society members.

The terms are Éjághám or Balondo, two languages common in southwestern Cameroon, of which Usaghade forms a part. Prince Mosongo agreed that Ékpè sources are "traced from Usak-Edet (Balondo land) in Cameroon. This is reinforced by the fact that most Ékpè songs [in southwest Cameroon] are in Balondo language' (Mosongo 1995, p. 80). As seen from these examples, linguistic evidence is fundamental to the identification of the sources of Ékpè in West Africa, a method already used to identify the West African source regions of Cuban Abakuá (Manfredi 2004; Miller 2005).

After searching the archives in Calabar, the only musical recordings I found were made by Èfik Ékpè; there were none by Ékpè musicians from Usaghade, Oban, and other ethnic settlements with Ékpè traditions. A thorough comparison with Cuban Abakuá would require a sampling of field recordings from Nigeria and Cameroon. Based upon the available evidence, however, we were able to identify many parallels with the abundant Cuban recordings. For example, a recording of Ékpè-style music made in Calabar entitled Nka Asian Mkparawa Eburutu (1981), translates as 'group of young proud Ėfik'. Two of the Èfik terms - Mkparawa 'youth'; Eburutu 'Èfik people' - correlate with the Abakuá terms unparawa 'neophyte' and burutón 'to talk language' (implying 'one who knows Èfik/Abakuá').

In Nigeria, Akpabot (1981, p. 88) implied that the stability of the content and structure of Ékpè ritual poetry make it useful as a source for historiography, writing that:

Èfik/İbibì ... ritual poetry is orientated strongly towards the continuity of a tradition therefore it has a well defined structure. The style is that of call and response with the cantor reciting his poem in song and the chorus supporting him intermittently.

Because Akpabot's statement applies to any generic West African or Niger-Congo culture, its application to the Cuban case proves nothing about Ėfik/Ìbibì sources. But it does identify dynamics fundamental to Cuban Abakuá. Akpabot (1981, p. 93) wrote that the 'ritual poet ... must be a member of the secret society of long standing, versed in the use of declamatory statements which have been handed down 
through the years .... Ritual poets do not compose their own material. What they do is bring their individual expertise to bear on an established traditional format.' Also, 'in ritual poetry, the message of the poet can only be understood by members and associates of a secret society ...' Each of these points are factors in Cuban Abakuá music.

\title{
Interpreting Cuban Abakuá codes in popular music
}

My documentation of Abakuá language enabled me to grasp its profound influence in commercial recordings of Cuban popular music. In an early essay, I wrote:

\begin{abstract}
Although hermetic and little-known even within Cuba, an analysis of Cuban popular music recorded from the 1920s till the present reveals Abakuá influence in nearly every genre .... Cuban musicians who are Abakuá members have continually documented key aspects of their society's history in commercial recordings [of popular dance music], often in Abakuá language. Because theirs is a secret language for initiates only, Abakuá have commercially recorded actual chants of the society, knowing that outsiders cannot interpret them .... Now played throughout the Americas, Africa, Europe, and Asia, Cuban popular music and its derivatives maintain Abakuá language and aesthetics as integral elements. Because so little has been written about the society by members themselves, commercial recordings with Abakuá content are an important source of knowledge about this group. (Miller 2000a, p. 161)
\end{abstract}

Due to its hermetic nature, Abakuá presence in Cuban popular music was often coded and elliptical. In this context, professional musicians who were Abakuá faced interesting challenges: on the one hand, the public liked the rhythmic and lyrical references to this underground culture; on the other, musicians could not reveal too much 'secret' language without fear of sanctions from Abakuá leadership. The public expression of ritual music was most famously associated with the 'afrocubanismo movement' of the 1920-1930s (see Moore 1997). But here I am referring to the rumba phrases with Abakuá texts created by and for the marginal communities who performed rumba for themselves. Such phrases were used selectively by professional musicians from these communities for commercial recordings. Many classic rumba texts from the nineteenth and twentieth centuries have not been recorded, but are known by masters of the tradition.

Many early recordings with Abakuá content were recorded outside of Cuba, usually in New York City, where musicians were free from sanctions by Abakuá leadership. Such restrictions continue to the present. For example, Cuba's famous dance band Los Van Van recorded 'Appapas del Calabar' in 1999, based upon narratives of Abakuá's foundation documented by Lydia Cabrera in her masterpiece La Sociedad Secreta Abakuá: narrada por viejos adeptos (1958) (Bolívar-Aróstegui, personal communication, 2000). Although it was a hit, they refrained from performing this in public in Cuba, as I witnessed in their concert of 1 January 2002, and as many Cuban musicians pointed out to me.

Abakuá codes in Cuban popular music were most famously used by 'Chano' Pozo (1915-1948), credited as the first to commercially record barrio-style rumba, a genre in which Abakuá musicians have long been prominent. ${ }^{2}$ Many of Pozo's compositions employ language play as a strategy for obliquely referring to the Abakuá. In 'Blen, blen, blen' (1939), Pozo's fusion of Abakuá, Kongo, 
Lukumí, and Arabic phrases creates what appears to be nonsense 'scatting', but speakers of the ritual languages can deduce esoteric meaning behind the verbal camouflage. The title was interpreted by a Cuban initiate of the Abakuá and Lukumí drumming guilds as a type of diana (reveille), a traditional form of vocalization used throughout Africa, Andalusia, Cuba, and the USA wherein the lead voice calls attention to itself in a prelude to a text. After opening with 'Blen, blen, blen', the lead sang:

Bonkoró yaré yaré bonkó yaré yaré/

Iyá mi bonkuére iyá mi.

The first line and the second chorus are based upon 'yare', a term derived from 'ìárrè!', an Ėdó ritual greeting meaning 'go and return', in effect, 'safe journey to the invisible world and safe return'. The phrase 'bonkuére iyá mi' was interpreted by a Cuban Abakuá musician as 'Bonkó iyá mí', meaning, 'the drum is my mother'. In Abakuá, 'Bonkó' is a title whose representative plays the lead bass drum that 'speaks'. In Ékpè, 'Èbònkó' is also a title, associated with the Universal Mother of the society who is in turn associated with a drum. In Lukumí (Cuban Yorùbá), 'iyá' is the mother or lead, bass drum that 'speaks' while the others follow. ${ }^{3}$ One message, then, of this composition is: 'The Abakuá bonkó and the Lukumí bàtá iyá are sacred mothers, both are drums that speak, instructing the other drums what to play.' By calling the drum 'my mother', the singer indicates reverence for Africanderived ritual traditions. The performance concludes with a solo drum 'speaking', as the Abakuá bonkó would during ceremony. The implications are that the emergence of one strand of contemporary Cuban identity is found in the practice of both Abakuá and Lukumí rites by the same person. In nineteenth-century Cuba, it was unusual that a 'Carabali' (a person from Calabar) would participate in 'Lukumí' culture, and vice versa. As African-born ritual leaders passed away, these traditions were maintained through the practice of both by the same person. A Cuban musician interpreted Chano's message as: 'in this creole union is the "iré" [Lukumí: good luck] of the Cubans'. That is, contemporary Cubans celebrate the diversity of their inherited practices as maintained by individuals with multiple initiations. As I stated earlier, African-derived phrases as recorded in popular music were not meant to be understood by the general public, but studious initiates can decode them.

Another rumba-structured composition by 'Chano' Pozo, 'Anana Boroco Tinde' (1940), plays with the Abakuá term 'baróko' (the initiation of title-holders), and 'tínde' (Africa), meaning 'an Abakuá ceremony performed as it was done in Africa' (see Cabrera 1988, p. 500).

Chano's coded word plays within a danceable rhythmic structure signal creative genius; the understated poetic references to Abakuá and Lukumí ritual actions signal a repressive environment requiring the camouflaging of these realities. In response to this context, 'coded performances in the Caribbean ... often have dual implications', as I have written about elsewhere (Miller 2000b, p. 30). Chano Pozo's coded compositions can be interpreted in detail by those who know the ritual phrases and their meanings; others might understand the phrases as 'scatting', as in the North American jazz tradition. 


\section{New York: Abakuá orthodoxy within a jazz context}

Cuban musicians and their music were present during the formative period of jazz music in New Orleans (Acosta 2003; Fernández 2006). Later on, from the 1940s onwards, Abakuá musicians migrating to New York contributed to the jazz culture there while expressing their identities as Abakuá representatives. After a successful career in Havana, Abakuá member 'Chano' Pozo helped create the bebop and Latin Jazz genres with Dizzy Gillespie in New York in the late 1940s. Pozo and Gillespie collaborated on compositions integrating Abakuá ceremonial music and chants with jazz harmonies, like 'Manteca' and 'Afro-Cuban Suite', performed in 1947 by the Gillespie Band.

The sheer power of their recorded performances continues to inspire. It is relevant to note, however, that Pozo was discreet in his performance of Abakuá language in the context of Dizzy's band. This becomes evident when compared to a studio recording of the same period, of a lengthy chant called 'Abasi' (1947), titled after the Abakuá and Cross River term for the Supreme Being. Whereas Pozo used 'Abasí' to develop a ritual theme with great detail and clear articulation, 'Afro-Cuban Suite' was a spectacle wherein Pozo displayed his emotive percussive abilities, while briefly introducing the three major legacies of Africa in Cuba by chanting loosely in Abakuá, then in Lukumí, and finally in Cuban-Kongo (Dizzy Gillespie/Max Roach in Paris, 1995). A further clue to Pozo's discretion is evident in Dizzy's performances of 'Afro-Cuban Suite' after Pozo's death in 1948. For decades afterwards, in recordings like 'Swing Low, Sweet Cadillac', Dizzy (1996) playfully reproduced Pozo's chanting, without knowing its meanings.

Following 'Chano' Pozo, several Cuban percussionists who migrated to the USA recorded Abakuá music within jazz-styled albums. In 1950, two Cuban members of Katherine Dunham's Ensemble recorded an Abakuá chant with piano accompaniment. Called 'Aferincomon' after Efori Nkomón, the oldest Abakuá lodge from an Efó lineage in Havana (founded in 1840), this chant also evokes Betongo Naroko, another Abakuá lodge founded in the nineteenth century. In Calabar, Efori Nkomón is interpreted as Efut Èkòmò, 'the drum of Efut', just as Cubans translate it. Betongo Naroko is understood (both in Cuba and in Africa) as an Efó (Efut) community in Usak-Ade. Of the two Cubans, Julio Mendez and LaRosa Estrada, Ms Dunham (personal communication, 2002) told me that the latter was an Abakuá initiate who danced Abakuá onstage to Mendez's drum solos.

In 1953, Mongo Santamaría recorded 'Abacua Ecu Sagare' (Abakuá Ékue Usagaré) in New York City with fellow Havana musicians. ${ }^{4}$ This 'folklore' recording evokes the mythical Abakuá ritual center of 'Usagaré', then several lineages in Cuba, and finally summons the Íreme masquerades to dance as the bonkó drum solo begins. The Íremes represent continuity and rebirth: continuity because these maskers oversee that rites are well done; rebirth because rites are performed annually. The performers had no way of knowing that the Usagare (Isangele) community existed in contemporary West Africa; they were repeating inherited phrases about their social history to proclaim their cultural achievements. But the meanings of these phrases were not meant to be understood by the general listening public.

In 1967, the LP Patato y Totico by Cuban musicians Carlos 'Patato' Valdés and 'Totico,' included two Abakuá tracks: 'Ya Yo E' and 'Rezo Abacua' (Abakuá 
Prayer). In 1972, Santamaría recorded the track 'Abacua' with Abakuá musician Julito Collazo, who migrated to the USA to play with Katherine Dunham's troupe in the 1950s (Collazo, personal communication, 2000).

Abakuá music recorded in the USA shows a strong African ethnic identity. For example, the cover of Mongo Santamaría's LP Up From the Roots (1972) depicts an ancient carved monolith from the Éjághám-speaking ('Ekoi') people of southeastern Nigeria, held by some to be the founders of Ékpè in the Cross River region (Thompson, personal communication, 2004; Eyo 1990 [1977]); this LP has an Abakuá track. Santamaría's recording Mongo \& Justo 'Ubane' (1976) is named after an Abakuá lineage in Cuba. ${ }^{5}$ Here, Collazo pronounces the term 'Obane'; in the Cross River region, Oban is an Éjághám settlement where Ékpè continues to be the local government. Again, the musicians had no way of knowing that Oban was a contemporary settlement in the Cross River; they were using recording technology to maintain and broadcast their oral tradition, but without revealing the content of the phrases to outsiders. These recordings in New York document the transition of Abakuá music to a jazz context, but at the same time document aspects of early nineteenth-century history and place names of the Calabar region.

In West Africa, as the concept of 'Old Calabar' expanded during the trade with Europe in the eighteenth and nineteenth centuries, from a small town to an entire region, Èfik became the lingua franca throughout the Cross River region, and Èfik culture became the model for 'civilization' (Uya, personal communication, 2004; Jeffreys 1935, I, p. 49; Ward 1911, p. 47). This explains why an Éjághám settlement like Oban would be remembered by Cuban Carabalí as an Ėfik region. For example, on 'Ubane', Julito Collazo chanted a reference to the Cuban lineage Obane: 'Obane, Ékue Efi okobio Obane' (Oban; the Ėfik Ékpè are brothers of Oban). This phrase is used in Abakuá practice to announce that the speaker is an initiate of an Obane lineage, believed to have been founded by nineteenth-century Cross River peoples in Cuba.

The function of Santamaría's 'Ubane' - like other Abakuá recordings made in New York by initiates or members of their extended communities - is to proclaim the survival of Abakuá culture through the self-affirmation of its members, while informing other Abakuá listeners that the performers have not forgotten their vows of commitment to the brotherhood. Implicit in this message is that earlier Abakuá leaders taught fellow members about their African sources in an orthodox manner, to the extent that they are recognizable in contemporary Calabar, and that this process must continue in the present.

Many of the musicians participating in the New York recordings were raised or socialized in centers for Abakuá activities, particularly the economically marginal barrios of Jesús María and Los Sitios. Their triumphs as recording artists in the northern metropolis were viewed as triumphs for their barrios. In other words, another layer of meaning in these recordings is tied to the concern of these musicians for representing the social institutions of their barrio. The music was meant to be enjoyed by dancing New Yorkers, but the coded phrases were meant to be understood by studious initiates in Havana and Matanzas. This approach was quite different from that of other composers of the 'Afrocubanismo' period in the 1920 and 1930 s, who went 'slumming' in the marginal barrios for ideas, then exploited AfroCuban ritual phrases for their exotic appeal to foreigners. The recordings referred to in this essay were created by the initiates themselves, or by musicians who, although 
not initiated, were from communities where Abakuá codes were generally understood. They used the ritual terms because they were part of their daily lives, but they did not teach their meanings to outsiders. By contrast, North American bandleader Cab Calloway (1939) created a dictionary to explain the meaning of 'hep' terms to enthusiasts of his music and its milieu. The difference in attitude was produced by the process of initiation: no erudite Abakuá musician would dream of transgressing his oath of discretion by explaining ritual terms in this way.

Even before Pozo's arrival to New York City, Abakuá influence was in the music. Mario Bauzá's 'Tanga', composed in New York City in 1943, is considered foundational to Afro-Cuban jazz; it became the theme song of Machito's Big Band. 'Tanga' is an Abakuá term meaning 'spiritual power' that is used in ritual practice to describe the very foundation of the Ékpè society in West Africa. The Abakuá chant: 'Tanga tongo nitanga nitongo, Ekue Usagaré', is interpreted as: 'the spiritual power in the gourd gave birth to Ékpè in Usagare'. Other forms of 'tanga' are used in the names of Havana lodges Usagaré Mutánga Efó and Ítánga Efí méremo; both existed before Bauzá's composition.

Bauzá's title 'Tanga', then, is one of many Abakuá terms incorporated into popular speech. In publications about this composition, however, 'Tanga' has been identified as an 'African' word meaning 'marihuana' (see Figueroa 1999, p. 10; DíazAyala 2002, 'Machito' entry). This interpretation might be inevitable given the nightlife context of this music, and even if perpetuated by the composer, it would be a quotidian, derivative interpretation that ignores the earlier Abakuá sources. Both bandleader 'Machito' (Frank Grillo) and composer Mario Bauzá were raised in Havana barrios with Abakuá traditions (Jesús María and Cayo Hueso, respectively); they would have known the ritual context of the term. In a 1949 recording, lead singer Machito informed that 'La Tanga llegó como ritmo' arrived as a new rhythm, then subsequently invited the public to dance along with the phrase: 'kle kle kle', taken directly from an Abakuá chant evoking the Íreme masks to dance ('kle kle kle' is onomatopoeic for the clappered bells they must use). This provenance is easily confirmed by comparison with Chano Pozo's 'Abasí' (1947), where the same phrase is used precisely in a purely Abakuá context. Machito then, was using a common trope in Cuban popular culture by speaking to two realities, the ceremonial and the recreational, in the same motion (see Miller 2000b). Another indication of the ceremonial subtext of this composition is found in a 1965 recording of 'Tanga' that Machito begins with by uttering: 'Iboru-iboya', a standard greeting to a babalawo, a diviner of Ifá, the classic divination system of the Yorùbá Diaspora.

A similar phenomenon occurred in Havana, when in 1952 pianist Bebo Valdés created a variant of the Mambo, calling it 'Batanga'. Valdés interpreted the term as a combination of 'batá' and 'tanga', his own invention to identify his new rhythm (Acosta 2003, p. 137). In fact, this is an Abakuá term related to musical dexterity: the dignitary Moruá Yuánsa is also known as 'Batanga Moruá', meaning 'one who chants a lot' (canta mucho). Using this Abakuá title, Justi Barreto (b. 1923) of the lodge Usagaré Mutánga composed 'Batanga No. 2' (Moré 1982). In Abakuá usage, referring to a popular rhythm as 'Batanga' implies that it is 'played a lot', 'has a lot of rhythm', or 'is frequently danced to'. As in the case of other Cross River terms like 'Usagaré' and 'Oban', the musicians may or may not have known that Batanga was an ethnolinguistic term in Cameroon that extended into the Cross River region. Only a small community of initiates would have understood the full Abakuá meanings of 
dance composition titles like 'Tanga' and 'Batanga', but they were an important community of cognoscenti with cultural influence in the wider society. Indications are that the use of ritual codes only increased in Cuban music over the decades. In the case of 'Batanga', in 1999 the Havana group Ventú Rumbero recorded a version of 'Batanga No. 2'. In the early twenty-first century Batanga was used as an Abakuá term in popular music, when NG La Banda director Jorge Luis Cortés recorded the phrase: 'you know that I am Batanga' (tu sabes que yo soy Batanga), then uttered an Abakuá phrase ending with 'Mokóngo Ma'chebere!' Meanwhile, the general dancing public was not necessarily concerned with these interpretations, but with enjoying this exquisite music that made their bodies move.

Another facet to Abakuá music recordings in New York is their orthodoxy, as in the already mentioned composition by 'Chano' Pozo, 'Abasí' (Abakuá Supreme Being). Far from the vigilance of Abakuá brothers who might disapprove of chanting detailed Abakuá phrases in a studio, Pozo recorded a ceremonial as it might be heard in an initiation. This was very different from his other compositions with Abakuá themes as recorded earlier in Havana, such as 'Muna Sanganfimba' or 'Anana Boroco Tinde'. These had cabaret style arrangements with piano and horns, and were performed in 'white only' casinos frequented by tourists.

Despite their use of coded language, Abakuá members in Cuba who have re-enacted ceremonial procedure in their performances for secular audiences have faced suspension or expulsion from the society. Ortiz (1981, pp. 444, 446) documented an example:

\begin{abstract}
Around 1928, in a theater of the city of Guanabacoa [near Havana], an [Abakuá] drama was presented ... composed and represented by real ñañigos [Abakuá] with the aim of exhibiting various picturesque Abakuá rites before the profane public in order to earn some money ... the improvised actors were 'suspended' or castigated by their 'potencia' or society, who viewed it as an irreverence, as if some clergymen had intoned the Te Deum laudamus in a cabaret.
\end{abstract}

In the same decade, popular musician Ignacio Piñeiro was barred from becoming a dignitary of his Abakuá group for using Abakuá lyrics in his compositions (Miller 2000a, pp. 172-173). The phrases would not have been understood outside the community of initiates, but Abakuá elders of the period were nevertheless strict in their prohibitions.

A score afterwards in New York, away from these restrictions of Cuba, Abakuá musicians recorded variations of ceremonial music, no doubt encouraged by the great interest among North American jazz musicians in learning about this music. If Pozo's 1947 'Abasi' was the first commercial recording of Abakuá ceremonial music, and Mongo's 1953 recording was the second, then the role of Abakuá music in the USA has been to create a tradition for commercially recording detailed Abakuá expressions not acceptable in Cuba at the time. The first 'folklore' recordings in Cuba were performed by Los Muñequitos de Matanzas in 1956 ('Ritmo Abacuá' 2001). In the same period the Grupo Afro-Cubano de Alberto Zayas recorded the detailed Abakuá track 'Acere' in Havana; after a pressing in Cuba, Panart released it in New York in 1960 (Díaz-Ayala, personal communication, 11 January 2007). In 1962 Abakuá leader Victor Herrera recorded 'Encame' with the support of Argeliers Leon of the National Theater (Música afrocubana 1993). In fact, several 
members of Victor Herrera's group Efí Yaguaremo were suspended from their lodges for their artistic activities (Pasos, personal communication, 2000; Lináres, personal communication 2005). This phenomenon is a sign of the tight network and orthodox taboos maintained among Cuban Abakuá regarding the public expression of their language and codes.

In later examples from New York City, Abakuá themes were inserted into 'AfroCuban jazz' as part of a Cuban identity by non-Abakuá members. In the 1980s in New York, Machito's Big Band recorded 'Yerbero' with the quotidian Abakuá phrase: 'Monina, aprosemi embara yenika' (brother, extend your hand to greet me).

Cuban trumpet player 'Chocolate' Armenteros's recording 'Harlem Latin Compas' (1994) celebrates the black Cuban musical culture transmitted to Harlem, including mambo, son-derived 'salsa', and an Abakuá chant praising the power of the bonkó drum: 'Heyey benkamá ... bonkó chemi ... manyongo pavio ... Ékue Usaga[ré]', precisely during a drum solo. 'Chocolate' is not Abakuá, but his allusion to the Abakuá presence in his Harlem neighborhood (since the 1940s with 'Chano' Pozo) is consistent with the feelings of many Cubans who are not members, yet understand enough of its codes to identify with and defend Abakuá (Armenteros, personal communication, 1995).

\section{West Africa: Ékpè ritual poetry}

The question of musical continuities between Africa and the Caribbean is not a romantic search for origins, but instead a facet of research that enables appreciation of the creative process of cultural transmission to the Western Hemisphere. A major problem with comparing Ékpè and Abakuá is the lack of available recordings from the Cross River region, with the added barrier of Ékpè being 'secret' and therefore rarely recorded. My imperfect solution was to create my own archives of audio field recordings, VHS and Mini DV footage, as well as manuscripts, in order to offer new evidence.

My function as Mbàkàrà is to bring Ékpè members more information about the impact of their traditions in the Americas. The Mbàkàrà title is used both in Nigeria and Cuba. Furthermore, my Ékpè lodge - Ékórétònkó - has a derivative lodge in Havana known as Ékuéri Tongó. The easy identification of these linguistic, ritual, and musical continuities has been fundamental to my interaction with both groups.

My Ékpè brothers introduced me to Mr. Demmy Bassey, an Ékpè member and former highlife musician who had played in Ghana in the 1960s. At my request, Mr Bassey transcribed, then translated, an LP recording of locally produced Ékpèstyle recordings ( $N k a$ Asian 1981); his work was then reviewed by formally educated Ékpè leaders (Etubom B.E. Bassey, personal communication). As Demmy transcribed songs, we learned that many were not Ékpè ceremonials, but used Ékpè aesthetics. This means that few early Ékpè recordings exist in Calabar, limiting our ability to conduct comparative studies with Abakuá.

What follows are three samples of contemporary Èfik Ékpè songs. Since Ékpè has many variants, we would not expect these Èfik chants to match easily with those of Cuban Abakuá, which are undoubtedly derived from various Cross River groups. This preliminary sample, however, contains themes closely paralleling those of Abakuá. 
Èfik

1. Ùsèm Ékpè ékèrè nsìbìdì àbànékpè ikpòng ódiòngó ùsèm émì úkèméké ndídiòngó ké múbànké Ékpè Èfik ímèmké; dá nsàn-nsàn!
English

/ Nsibììi is the language of Ékpè

/ only members understand the language

/ you can't know unless you are initiated

/ Èfik Ékpè is complex; keep off! (Nka Asian 1981)

The first term in line two, 'àbànékpè', has the same meaning and pronunciation as in Cuba. Ékpè initiates are taught a sign language (Nsibìdi) and ritual chants. Just as in Cuba, these vocalized, drawn, and gestured codes are understood only by trained members. Cuban Abakuá music is called 'ibiono'; a similar term in Èfik term means 'a barrier', that is, meant only for the initiated. As this Ėfik song tells us, the language and signs are not understood unless one is trained.

2. Ètè itíè ntè àmì

Dí ikà ké èfé

Òmódiòngó nsìbìdì Ékpè

Dí sèm ìsé kàbádé nò nyìn
/ you compare yourself with me

/ let us go to Ékpè shrine

/ do you understand nsìbìdì Ékpè

/ come and listen and interpret for us. (Nka Asian 1981)

This phrase is a challenge from one to another about their ability to interpret Ékpè signs and language. This contrapuntal structure is fundamental to Abakuá performances, where masters meet in a circle called 'la valla' to debate Abakuá lore about their mythic African history, while the drum ensemble plays supporting rhythms.

\section{3. Àbàsì ké ènyóng; nyàmkpè ké ísòng (Àbàsì édì ỉbà).}

God is in the heavens; Nyàmkpè is on earth (there are two Gods).

The Abakuá phrase 'Endáfia awereke Abasí obón Efi' conveys a similar concept: 'God in heaven and the Abakuá on earth' (Ortiz 1954, p. 40; Cabrera 1988, p. 386).

One interpretation of the phrases in example three is that Calabar people used them in response to early Christian missionaries who challenged their royal Ékpè practice. In the Calabar region in 1857, Reverend Hope Waddell (1863, p. 614) reported that the wives of King Eyo Honesty II protested Missionary attempts to change their customs: 'Missionaries, according to them, would spoil the country ... It were better we took our God, and went away to our own country, for black man's god would do for them.' In other words, 'the Christian God may be in the sky, but our Ékpè controls the land'.

Demmy Bassey and other Ékpè listened to the Ibiono (2001) recording I had brought from Havana, the most complete recording of Abakuá ritual music to date. They recognized many terms, and also identified the Cuban rhythms as those of the Èbònkó Ékpè title (there are five major Ékpè rhythms in the Èfik tradition of contemporary Calabar that correspond to specific grades). Not surprisingly, 
Calabar Ékpè responded enthusiastically to early recordings of Cuban Abakuá music, specifically Sexteto Habanero's 'Criolla Carabali', recorded in 1928 in New York. They also identified the rhythm of this track as that of the Èbònó title.

Cultural concepts and language expressed both in Ékpè and Abakuá chants indicate the rich variation of continuities between West Africa, the Caribbean, and the USA.

\section{A preliminary comparison of Ékpè and Abakuá music}

Upon my return from Calabar in 2005, Abakuá title-holder and professional musician 'Roman' Díaz examined my audio-visual recordings of Ékpè music in the Calabar region (Oban, Nsofan, and Calabar South), as well as the Nka Asia (1981) audio recording, identifying obvious relationships between the structure of Ékpè and Abakuá instruments and the ways of playing them, but great differences in the singing styles. ${ }^{6}$ But the structure of both Abakuá and Ékpè songs has a preliminary vocal statement before the percussion begins, and uses call and response between a lead voice and chorus throughout. Ékpè songs use a style akin to hocketing while the lead voice sings boastful proverbs with much repetition; Abakuá songs often use a narrative style that can become epic in length and content.

On both sides of the Atlantic, leopard society percussive instruments are made with similar materials (wood, metal, animal skin, reeds, and seeds); the drums have the same technique of tightening the membrane with wedge-shaped pegs, are played with the same hand techniques, and each drum, called 'nkomo' in Cuba and 'èkòmò' in Ėfik (Goldie 1964 [1862], p. 73), has the same function: the longer lead drum solos while the shorter drums play interlocking supporting rhythms. In both regions the long drum is called a 'talking drum' because it directs the movements of the dancer. The handling of this drum is also consistent in Africa and in Cuba: during processions, all small drums are carried in the hands, while the long drum is held with a strap around the shoulders so that both hands can play the skin. In Havana, Cuba, while an ensemble is stationary on the temple grounds, the lead drum is held with a strap at the waist of a standing drummer; in Matanzas it is held upright between the legs of a seated drummer. In the Cross River, this lead drum is either played upright between the legs of a drummer seated in a chair, as in Matanzas, or placed lengthwise upon the floor and sat upon by the player, who also uses the heel of his right foot on the drum skin. In Cuban lodges during the 'nyoro' or funerary rites, the lead drum is commonly placed on the floor and straddled by the drummer, as in the Calabar region. Both Ékpè and Abakuá use a metal idiophonic bell to play timeline patterns, as well as reed shakers with seeds inside them to play another rhythm. A difference is that in Cuba, the 'ekón' bell has been used since the 1950s to play an Abakuá clave rhythm (the same as that of the rumba-guaguancó), while in Calabar the 'nkóng' plays a different time-line pattern, one played in Cuba on a third, supporting drum. That is, in Calabar three drums and an 'nkóng' are generally used, while in Cuba there are four drums and an 'ekón'. As a general rule, there are more variations in Cross River Ékpè drumming than in Cuban practice. For example, five of the nine major Ékpè titles of Calabar have their own rhythm and dance styles, while Cuban Abakuá have generally a faster and slower pace (representing Efí and Efó styles) using the same rhythms (see Ortiz 1965, p. 432). In Cuba the rhythmic 
paces have regional variants: in Matanzas the style of playing is generally slow, without distinction between 'Efó' and 'Efí', while in Havana players distinguish between 'Efó' with a slow pace, and 'Efi' with a fast pace. For examples, compare the track 'Abakuá' of Grupo Afro-Cuba de Matanzas with the track 'Bacoco Efó' of Ibiono (recorded by Havana masters). Both have a similar pace, while the 'Apapá Efí' track of Ibiono is much faster (Guerero, personal communication, 2009).

The Cuban use of four drums is part of West African Ékpè practice. One Ékpè title, Nkàndà, uses four drums, as I saw performed by the Osam Mgbè Big Qua Town in 2005. A photograph of an Nkàndà Ékpè ceremony in Uruan in the 1930s showed the use of five drums (Miller 2009, p. 194). Given the available evidence, I can confidently reason that aspects of the Cross River Ékpè traditions of Nkàndà with its four drums, and Ebongo and its rhythms, were recreated in colonial Cuba.

Both Ékpè and Abakuá initiation rites require a reverberating sound that signals the activation of the mystical aspects of their systems. Abakuá call it 'The mystic Voice of the Leopard', while Ortiz (1955, p. 236) called it an 'instrumentum regni'. Being at the core of Ékpè/Abakua practice, The Voice is not discussed publicly by members. Many Abakuá have lost their membership by displaying inappropriate curiosity about it, while many scholars who have written about it have not actually seen it. What is important is the sound itself, not what produces it. Only after years of respectful study in Cuba, and then initiation in Calabar, was I invited to discuss this aspect of Ékpè-Abakuá continuity with Cuban leaders. Because this sound is sometimes referred to as the 'Bongó', Abakuá utter the phrase 'Bongó Itá' (One Voice) to mean that all lodges in the brotherhood are equal, since the Voice of each is regarded to have the same divine power. ${ }^{7}$ The concept expressed through 'Bongó Itá' in Cuba is pervasive in Ékpè practice throughout the Cross River region. Among Èfik and Efut of the Calabar region I learned the variant phrase: 'Úyò Mbókò kpúkpùrù édì kièt' (the sound in all the Ékpè lodges is only one) (Ika, personal communication, 2005). After viewing my video footage of Ékpè ceremonies in the Cross River region, Abakuá leaders in Havana were satisfied that the sound emerging from those inner sanctums was the determining evidence that the African and Cuban traditions are intimately related.

\section{Conclusion}

Being a hermetic non-proselytizing group, Cuban Abakuá do not want to be studied. When I learned of their strong interest in confirming their West African sources, however, I began to share with them information about the Cross River Ékpè to the great satisfaction of many. As one Abakuá leader told me, 'after learning about Ékpè in Africa, we understand that we are not alone in the world'. Cross River Ékpè, in turn, seem to have a similar attitude towards the Abakuá, a signal of the political use of inherited cultural systems on both sides of the Atlantic.

The process of transmission from Cross River to Cuba was a creative process of adaptation to this Caribbean society that became foundational to its urban social networks and musical culture. The strong taboos against the public expression of Abakuá language in Cuba, on the one hand a form of defense against the historic opposition to this mutual-aid society by colonial and Cuban administrations, on the other a form of orthodox control by the Abakuá leadership, resulted in sanctions against some musicians who recorded Abakuá chants throughout the twentieth 
century. In New York City, where Abakuá musicians were freer from taboos, their contributions of Abakuá expression to jazz aesthetics was also a creative process that influenced the direction of bebop music and other forms of jazz.

The impact of Abakuá on popular music in Cuba and the USA has been tremendous, a theme I have treated elsewhere (Miller 2000a). It is remarkable that the Abakuá cultural movement has been able to expand from ritual secrecy in Havana onto the global stage of popular music, via bebop in Manhattan, entirely in the oral medium while maintaining some degree of intelligibility of its texts to current Cross River practitioners of Ékpè - the source tradition from which it was separated some 200 years ago. As with other cases of oral transmission across long time and space intervals, such as the Vedic and Homeric poems, the Abakuá example combines intensive artistic discipline with a ritualized guild framework. As the present moment of history is witnessing the reconnection of the two ends of this vast diasporal arc, the impact of this encounter on the local communities of practitioners will be fascinating to observe. At the same time, the public nature of the new encounter is eliciting unprecedented openness from all sides, to scholarly access, which promises to enrich the description of each of the local traditions which were heretofore so closely guarded from outside view. Eventually the global Ékpè-Abakuá network may develop its own organic scholarship from within, such has happened already to an extent with the Yorùbá-Lukumí tradition.

\section{Acknowledgements}

Research for this essay was supported by a Rockefeller Resident Fellowship through the Center for Black Music Research, Columbia College Chicago 2005-2006; an extended Fulbright Grant to Nigeria (2009-2011); the Vice-Chancellor of the University of Calabar, Professor James Epoke. Thanks also to Sunday Adaka, Nath Mayo Adediran, John Amira, Asuquo O. Anwana, 'Etubom' Bassey Ekpo Bassey, 'Engineer' Bassey Efiong Bassey, Ken Bilby, George Brandon, Jill Cutler, Cristóbal Díaz-Ayala, 'Román' Díaz, Mario 'Chavalonga' Dreke-Alfonso, Shannon Dudley, Chief Eso Archibong Eso, Professor Okon Essien, Dr Ako Essien-Eyo, Senator Bassey Ewa-Hanshaw, Raul A. Fernández, Samuel A. Floyd, Jr, Maxine Gordon, Angel Guerrero, Alexandre Jomaron, Gerhard Kubik, Robin Moore, Michael Gomez, Joseph Inikori, Victor Manfredi, Lynn Miller, Obong Bassey A. Nyong, Ntufam I. Ntui Erim Onongha, (Lt Col. Ret.) Ernesto 'El Sambo' Soto-Rodríguez, Robert Farris Thompson, Professor Eskor Toyo, and various Abakuá members who wish to remain anonymous.

\section{Notes}

1. Ékpè is the Èfîk term, Ngbè (or Mgbè) is Éjághám, and Obè is the term in Isangele (Usaghade/Usak-Edet); see Nicklin (1991).

2. Rumba is a complex of poly-rhythmic percussive music with call and response singing, traditionally performed in black working-class Cuban communities. It was historically performed in private homes or the collective patios of tenements called 'solares'. A key figure in the history of the rumba complex is Abakuá member Ignacio Piñeiro (1888-1969) founder of the 'son' group Septeto Nacional in 1927.

Pozo's recordings in New York City in 1947 are considered the first commercial recordings of solar-style rumba, that is, percussion with no horns. One of these, 'Abasi' is an Abakuá chant (see Martré and Méndez 1997, p. 60; Pujol 2001, pp. 59, 111; Sublette, personal communication, 27 August 2001). The term 'rumba' has been indiscriminately applied to all forms of Cuban popular music, including son, guaracha, and troubador songs. One writer claimed that the first rumba recordings were made in 1906 for 
Edison on two-minute cylinders, such as 'La reina de la rumba' (Ed-14154) and 'Mamá Teresa' (Reyes-Fortún 2000, p. 34). These, however, are not rumbas, but according to musicologist Cristobal Díaz Ayala (2002), 'were called since the end of the nineteenth century "rumbitas" [little rumbas], which were really sones [in the son genre] played rapidly, accompanied with mono-rhythms, not poly-rhythms' (see Carpentier 1989, p. 228).

3. Furthermore, in Ėfik, 'iyak' is fish (Goldie 1964 [1862], p. 142), and according to Abakuá mythology, a representation of Mother Nature that enabled the creation of the Ékpè society. For this reason, 'iyá' can be interpreted as 'mother' in Abakuá.

4. Mongo Santamaría (1917-2003) was born in Jesus Maria (Giro 2007 vol. 4, p. 132; Leymarie 2002, p. 195). He was not Abakuá, but many members of his extended family were. His uncle Roberto Izquierdo held the title Nkóboro of the Efó Kondó lodge of Havana. Izquierdo's son (Mongo's cousin), 'Pello el Afrokan', was a member of the same lodge, who created the Mozambique rhythm that raged in Cuba of the 1960s (SotoRodríguez, personal communication, 2006).

The track 'Abacua Ecu Sagare' was released in 1953, then re-released later in the decade. Silvestre Méndez arranged and performed the lead voice in 'Abacua Ecu Sagare' (see Fernández 2006, p. 92; Gerard 2001, pp. 41-42, 46; Martré and Méndez 1997, pp. 60-62).

Silvestre Méndez (b. 1921, Jesus María, d. 1997, Mexico), a rumba player and composer from the Havana barrio of Jesús María, was Chano Pozo's brother-in-law. An 'ndisime' (neophyte) of the lodge of his father, Ekerewá Momí, Méndez left for Mexico in 1945 and never returned. Méndez recorded the track 'Ñáñigo' for the LP Bembé Araguá; it seems to have been recorded in New York, 1957, for Victor: V-MKS-1361 (Díaz-Ayala 2002; Martré and Méndez 1997, p. 60).

5. Popular singer Justo Betancourt is an Obonékue of the Matanzas lodge Efí Guéremo (Guerrero, personal communication, 2007).

6. My recordings in the communities of Oban (Akamkpa L.G.A.), Abijang and Nsofan (Etung L.G.A.), and Calabar (in the Ėfé Ékpè Éyò Émà - Ékórétònkó, as well as the Osam Mgbè Big Qua Town) were made under the direction of the local Ékpè title-holders inside their Ékpè halls.

7. In Cuba, 'ita' is one, whereas in Èfik it means 'three'. This difference has a mythological explanation according to Cuban sources: during the creation of the original Bongó in Usagaré, three brothers (representatives of three local groups) were consecrated to receive it, therefore becoming 'one' in their intentions and thoughts. In addition, an Ékpè chant used in Calabar uses the parallel phrase 'èkòmò itá':

Èkòmò itá, èkòmò ìnàng (three drums, four drums)

Èkòmò ósio mi ke ufòk ókosùk ké ánwá ékòmò

(One of the drums removes me from the house to outside). (Chief Eyo, personal communication, 2005).

Ita is also a personal name in Calabar, where a son is named after a father. By the third generation, a grandson would have three identical names, and use 'Ita' to mean 'the third'. Thus in Calabar, Ékpè Ita (Ékpè the third), was the name of a musician whose recordings of Ékpè-styled compositions were examined during research for this essay (see 'Ase' - Traditional).

\section{References}

\section{Printed materials}

Acosta, L., 2003. Cubano Be Cubano Bop: one hundred years of jazz in Cuba. Washington, DC: Smithsonian Books.

Akpabot, S.E., 1975. İbibì̀ music in Nigerian culture. East Lansing: Michigan State University Press.

Akpabot, S.E., 1981. Musicological approach to Èfik/İbìbì̀ oral poetry. In: U.N. Abalogu, G. Ashiwaju and R. Amadi-Tshiwala, eds. Oral poetry in Nigeria. Lagos: Nigeria Magazine. Anwana, A.O., 2009. Ékpè Imperium in south-eastern Nigeria, 1600-1900. Calabar: African Pentecost Communications. 
Cabrera, L., 1958. La Sociedad Secreta Abakuá: narrada por viejos adeptos. La Habana: Ediciones C. R.

Cabrera, L., 1988. La Lengua Sagrada de los Ñañigos. Miami: Colección del Chicherekú.

Calloway, C., 1939. The new Cab Calloway's cat-ologue, rev. edn. New York: n.p.

Carpentier, A., 1989 [1946]. La música en Cuba, 2nd ed. La Habana: Editorial Pueblo y educación.

Díaz-Ayala, C., 2002. Cuba Canta y Baila: encyclopedic discography of Cuban music 1925-1960. Available at: http://gislab.fiu.edu/SMC/about.html.

Eyo, E.O., 1990 [1977]. Two thousand years of Nigerian art. London: Ethnographica.

Fernández, R.A., 2006. From Afro-Cuban rhythms to Latin jazz. Berkeley: University of California Press; Chicago, IL: Center for Black Music Research, Columbia College.

Figueroa, F.M., 1999. Liner notes to Machito Baila baila baila: 1943-1948. East Sussex, England: Harlequin, HQ CD, 139.

Gerard, C., 2001. Music from Cuba: Mongo Santamaría, Chocolate Armenteros, and Cuban musicians in the United States. Westport, CT: Praeger.

Giro, R., 2007. Diccionario enciclopédico de la música en Cuba. 4 tomos. La Habana: Letras cubanas.

Goldie, H., 1964 [1862]. A dictionary of the Efik language. London: Gregg Press.

Hall, G.M., 1992. Africans in colonial Louisiana. Baton Rouge: Louisiana State University Press.

Herskovits, M.J., 1948. The contribution of Afroamerican studies to Africanist research. American Anthropologist, 50 (1), part 1 (Jan.-March), 1-10.

Jeffreys, M.D.W., 1935. Old Calabar \& notes on the İbibiò language. Calabar: H.W.T.I. Press.

Landers, J., 1999. Black society in Spanish Florida. Urbana: University of Illinois Press.

Leymarie, I., 2002. Cuban fire: the story of salsa and Latin jazz (trans. from the French original, published 1997). London: Continuum.

Manfredi, V., 2004. Philological perspectives on the southeastern Nigerian diaspora. Contours: A Journal of the African Diaspora, 2 (2), 239-287.

Martré, G. and Méndez, S., 1997. Rumberos de ayer: músicos cubanos en México (1930-1950). Veracruz, México: Instituto Veracruzano de Cultura.

Miller, I., 2000a. A secret society goes public: the relationship between Abakuá and Cuban popular culture, African Studies Review, 43 (1), 161-188.

Miller, I., 2000b. Religious symbolism in Cuban political performance. TDR: A Journal of Performance Studies, 44 (2) (T166), 30-55.

Miller, I., 2005. Cuban Abakuá chants: examining new linguistic and historical evidence for the African Diaspora. African Studies Review, 48 (1), 23-58.

Miller, I., 2009. Voice of the leopard: African secret societies and Cuba. Jackson: University Press of Mississippi.

Moore, R.D., 1997. Nationalizing Blackness: Afrocubanismo and artistic revolution in Havana, 1920-1940. Pittsburgh, PA: University of Pittsburgh Press.

Mosongo, Prince Njong Effiong-Offiong, 1995. An X-ray on Bakassi Peninsular (let's save it). Ekondo Titi, Cameroon: Self-published.

Nicklin, K., 1991. Un emblème Ejagham de la société Ékpè/An Ejagham emblem of the Ékpè society. Art Tribal (Bulletin annuel publié par l'Association des Amis du Musée BarbierMuller), pp. 3-18.

Ortiz, F., 1954. Los instrumentos de la música afrocubana, Vol. 4. La Habana: Cárdenas y Cía.

Ortiz, F., 1955. Los instrumentos de la musica afrocubana, Vol. 5. La Habana: Cárdenas y Cía.

Ortiz, F., 1965 [1950]. La africania de la música folklórica de Cuba, 2nd edn. La Habana: Editora Universitaria.

Ortiz, F., 1981 [1951]. Los bailes y el teatro de los negros en el folklore de Cuba. La Habana: Letras Cubanas.

Pujol, by Jordi, 2001. Liner notes to: Chano Pozo: el tambor de Cuba, vida y música del legendario rumbero cubano. Tumbao Cuban Classics, vols 1-3. Barcelona, Spain, $143 \mathrm{pp}$.

Reyes-Fortún, J., 2000. 50 años de rumba en la discografía cubana. Revista Salsa Cubana, 4 (11), 33-37.

Trujillo y Monagas, D.J., 1882. Los criminales de Cuba. Barcelona: Fidel Giro. 
Waddell, Rev. H.M., 1863. Twenty-nine years in the West Indies and Central Africa: a review of missionary work and adventure, 1829-1858. London: T. Nelson and Sons.

Ward, Rev. W.J., 1911. In and around the Oron Country; or the story of primitive Methodism in southern Nigeria. London: W.A. Hammond.

Wood, P.H., 1974. Black majority: Negroes in colonial South Carolina. New York: Alfred Knopf.

\section{Sound recordings and oral interviews}

Armenteros, Chocolate, 1994. 'Harlem Latin Compas'. Chocolate Aqui. Carib Musicana. CCD-2081.

Armenteros, Chocolate, 1995. Interviews with the author in Chocolate's home, NYC. 26/2; $29 / 5$.

'Ase' - Traditional, 1975. Ima Edi Obio Group, led by Ekpe Ita. Philips. 6361-109 (LP), made in Nigeria.

'Ase' - Traditional, Vol. 2. 1976. Ima Edi Obio Group, led by Ekpe Ita. Produced and directed by Chief Inyang Henshaw, 636-1187 (PL) Stereo.

Bassey, 'Etubom' B.E., 2004-2005. Etubom Bassey (d. 2010) was Obon Iyamba of the Ėfé Ékpè Éyò Émà (Ékórétònkó) lodge of Calabar. Conversations with the author. Calabar, Nigeria.

Bassey, Demmy, 2004. Mr. Bassey (d. 2008) was a member of the historic Coco Bassey compound of Àtákpà (Calabar). In Ghana, his compositions were recorded by the Black Beats, the Ramblers Band, and E.T. Mensah in the 1960s.

Bolívar-Aróstegui, Natalia. 2000. Conversations with the author in Havana.

'Chano' Pozo, Luciano. 2001. 'Abasí'. 'Chano' Pozo, recorded in 1947 in New York City:

'Anana Boroco Tinde' (rumba afro), 'Muna Sanganfimba', Miguelito Valdés con la Orquesta Havana-Riverside, both recorded in 1940; 'Blen, blen, blen' (rumba afro). Miguelito Valdés con la Orquesta Casino de la Playa, recorded in 1939. Chano Pozo: el tambor de Cuba, vida y música del legendario rumbero cubano. Text by Jordi Pujol, vols 1-3. Tumbao Cuban Classics, TCD 305.

Collazo, Julito, 2000. Interviews by the author with Sr Collazo in his home, New York City, 28 February 2000 and 2 April 00. Revised by Collazo and Miller, 2 April 2000.

Díaz Anaya, Ogduardo 'Román, 2005. Conversation with the author in the USA. A titleholder of the Cuban lodge Ékuéri Tongó, Mr Díaz was a percussionist with the rumba group Yoruba Andabo in the 1990s.

Dizzy Gillespie, 1996. 'Swing Low, Sweet Cadillac'. Impulse Records [1967].

Dizzy Gillespie/Max Roach in Paris, 1995. 'Afro-Cuban Suite'. BMG Music, CD 0902668213-2.

Dunham, Katherine. 2002. Interview conducted in Katherine Dunham's home in New York City, in the presence of her daughter Marie-Christine Dunham Pratt and Ms Hill, 30 December. On 8 May 2003 I reviewed this material with Ms Dunham.

Eyo, Chief Effiom Ekpenyong, 2005. Conversations with the author, December. Chief Eyo (d. 2011) was Mbókò-mbókò of the Ėfé Ékpè Éyò Émà (Ékórétònkó) lodge of Calabar.

Grupo AfroCuba: Raíces Africanas/African Roots, 1998. 'Abakuá'. Recorded February 1996, EGREM studios in Havana. Shanachie 66009.

Grupo Afro-Cubano de Alberto Zayas, 1960. 'Acere'. Afro-Frenetic: Tambores de Cuba. Panart Recording Corp., 276 Park Avenue. LP-3053 (recorded in Cuba, released in New York).

Guerrero, Angel, 2007, 2009. Mr Guerrero holds the title of Aberiñan in the Havana lodge Itia Mukandá Efó. Conversations with the author in the USA.

Ibiono, 2001. Recorded in Havana, 2001. Caribe Productions, CD 9607. 
Ika, Etim, 2005. Conversations with the author, Calabar, December. 'Prince' Ika is the son of the Muri Cobham Antigha Edet $4^{\text {th }}$ of Efut Ifako Clan, Creek Town, Odukpani L.G.A.

Katherine Dunham \& Ensemble, Afro-Caribbean Songs \& Rhythms. 1950. 'Aferincomon (Nanigo), Afro-Cuban Cult Chant', sung by Julio Mendez. 10", Decca DL-5251 (described as 'a cult song of the secret, exclusively male society of Batonga Naroca', Decca 40029A).

Lináres Savio, Dra. María Terésa, 2005. DV-tape recorded interviews in the home of Dra. Linares, October. Dra. Linares is the former director of El museo de la música, La Habana.

Machito and his Salsa Big Band, 1988. 'Yerbero'. Composed by Raul Grillo 'Machito'. 1983 Grammy Award Winner. Impulse/MCA Records, Inc. Recorded in 1982 in Fendal Sound Studios, Holland.

Machito, 1989. 'Tanga'. Mucho mucho Machito. Recorded at Capitol Studios, New York City, 20 May 1965. Palladium Latin Jazz \& Dance Records, PCD 119.

Machito and His Afro-Cuban Orchestra, 1993. 'Tanga'. Composed by Mario Bauza. Recorded January 1949 in New York, with Flip Philips on tenor sax. The Original Mambo Kings: an Introduction to Afro-cubop. Verve 314-513-876-2.

Mongo Santamaría, 1953. 'Abacua Ecu Sagare.' Chango: Afrocuban Drums. LP-1037.

Mongo Santamaría, 1972. 'Abacua', by Julito Collazo. Up From the Roots. Atlantic.

Mongo Santamaría and Justo Betancourt, 1976. Mongo \& Justo 'Ubane'. 'Ubane' (Canto Abacua), by Julito Collazo, Vaya Records, New York, VS-44.

Moré, Beny, 1982. 'Batanga No. 2', written by Jústiz Barreto. Recorded by Moré in 1955. Sonero mayor. vol. VIII, EGREM, LD-4061.

Los Muñequitos de Matanzas, 2001. 'Ritmo Abacuá'. Grabado en La Habana 1956-1963, TDC 707.

Música afrocubana, 1993. 'Encame'. Viejos cantos afrocubanos: antología de la música afrocubana, vol. 1, performed by Victor Herrera, EGREM, La Habana, C 3325.

Nka Asian Mkparawa Eburutu: Cultural Group Calabar, recorded in 1981, Ekondo Records, Calabar, Nigeria, ERLP 001. Director, 'Etubom’ Asuquo Etim.

Pasos, Gerardo 'El Chino', 2000. Sr Pasos (d. 2002) was the Mokóngo of Kamaroró Efó, an Abakuá group from Havana.

Patato y Totico, 1967., 'Ya Yo E'; 'Rezo Abacua'. Recorded 19 September 1967, New York City. Original: Verve, V6-5037; second release: MDC-10065.

Sexteto Habanero, 1995a. 'Criolla Carabali', written by Guillermo Castillo, recorded 29 May 1928, New York. Sexteto Habanero 1926-1931, Harlequin HQ CD 53, England.

Silvestre Mendez y su tribu afrocubana, 1957. 'Ñañigo'. Bembé Araguá. RCA Victor, Mexico, MKL 1361.

Uya, Okon E., 2004. DV recorded interview with Professor Uya, August, Department of History, University of Calabar, Nigeria.

Los Van Van, 1999. 'Appapas del Calabar', Llegó ... Van Van. Havana caliente - Atlantic, 832227-2. 